\title{
Nilai Edukasi Candi Jabung Kecamatan Paiton Kabupaten Probolinggo Dalam Pembelajaran Sejarah
}

\author{
Eko Muhammad Arif Budiono1, Bambang Soepeno', Rully Putri Nirmala Puji1 \\ ${ }^{1}$ Afiliasi (Program Studi Pendidikan Sejarah Fakultas Pendidikan dan Ilmu Pengetahuan Sosial \\ Universitas Jember, Jalan Kalimantan No.37 Jawa Timur 68121, Indonesia) \\ Email: ekoarifin9@gmail.com
}

Received 25 May 2019; Received in revised form 30 June 2019; Accepted 24 August 2019

\begin{abstract}
Abstrak
Candi jabung adalah candi peninggalan sejarah dari kerajaan majapahit di kabupaten probolinggo yang berada di desa jabung candi, situs peninggalan candi ini masih belum maksimal digunakan dalam pembelajaran sejarah. Penelitian ini bertujuan untuk mengetahui nilai edukasi yang terdapat pada candi jabung sehingga dapat membantu dalam pembelajaran di kelas untuk peserta didik. Penelitian ini adalah penelitian analisis/deskriptif tentang nilai edukasi yang terkandung pada candi jabung. Tempat penelitian adalah desa jabung candi kecamatan paiton tempat candi jabung berdiri. Metode penelitian yaitu metode penelitian kualitatif. Kajian yang diteliti adalah nilai edukasi yang terkandung pada candi dalam penggunaanya di pembelajaran sejarah. hasil dari penelitian ini adalah Candi Jabung disebut dengan nama Bajrajinaparamita Candi. Candi jabung pernah disinggahi oleh Maha Raja Hayam Wuruk ketika mengadakan perjalanan kedaerah timur Jawa. Ketika sampai di Paiton dapat dimanfaatkan diantaranya sebagai sumber belajar dikelas dan sebagai bukti nyata peninggalan sejarah disekitar peserta didik. Simpulan terdapat nilai edukasi yang terkandung dalam candi jabung ini dalam pembelajaran sejarah.
\end{abstract}

Kata kunci: Candi Jabung, hayam wuruk, majapahit.

\begin{abstract}
Jabung Temple is a historical heritage temple from Majapahit Kingdom in Probolinggo Regency, which is located in Jabung Candi Village, this temple heritage site is still not maximally used in history learning. this study aims to determine the value of education contained in the temple jabung so that it can help in class learning for students. This study is an analytical / descriptive study of the value of education contained in jabung temples. The research site is the jabung candi village in Paiton sub-district where the temple of jabung stands. The research method is by kualitative method. The study studied was the value of education contained in the temple in its use in historical learning. the result of this research is Jabung Temple called Bajrajinaparamita Candi. Candi Jabung was visited by Maha Raja Hayam Wuruk when traveling east of Java. The area passed by Lasem, Lohdaya, Palah Lawang, Blitar, Jime, Simping, and Kalayu. When you get to Paiton, you can use it as a learning resource in the classroom and as a tangible proof of historical heritage around students. The conclusion is of course there is an educational value contained in this jabung temple in learning history.
\end{abstract}

Keywords: Jabung Tample, Hayam Wuruk, Majapahit.

\section{PENDAHULUAN}

Indonesia adalah negara kesatuan yang terdiri dari berbagai suku bangsa yang memiliki kekuasaan yang luas namun sebelum terbentuknya negara kesatuan yang disebutkan dalam pancasila yang berada pada sila ke tiga, sejarah negara
Indonesia sendiri menurut Moh. Yamin Indonesia sebelum menjadi NKRI dijadikan sebgai kerajaan dengan melalui tiga bentuk kekuasaan yang pertama dari kerajaan Sriwijaya, dibawah Wangsa Syailendra, dengan ciri kedatuan. Kedua kerajaan Majapahit 
yang berupa keprabuan. Kedua tahapan tersebut merupakan cikal bakal dari Indonesia kini dan tahapan ketiga adalah NKRI.

Pada tahapan yang kedua adalah tahapan yang dikuasai oleh Kerajaan Majapahit (1293-1525). Wilayah yang dikuasai oleh Majapahit semasa jayanya itu membentang dari Semenanjung Malayu (sekarang Malaysia) sampai Irian Barat melalui Kalimantan Utara. Majapahit sendiri menjadi negara yang sangat besar pada masanya, Majapahit mengalami masa kejayaan pada Raja Hayam Wuruk. Raja Hayam Wuruk selalu dipuja karena berhasil mengalakan musuh musuhnya, pajak pajak mengalir masuk bagai air.

Maha Raja Hayam Wuruk meninggal di Trawulan hal ini berdasarkan berita Cina pada tahun 1377 menyatakan bahwa Ibukota tempat bersemayam Dyah Hayam Wuruk disebut Kedaton Kulon (Muljana, 1983:222). Sepeninggalnya Maha Raja Kerajaan Majapahit mengalami keretakan karena penerus selanjutnya tidak secakap raja terdahulu ditambah lagi dengan kekosongan jabatan Maha Patih Gajah Mada yang kosong selama tiga tahun, kekosongan tersebut dijelasakan oleh Kitab Pararaton yang kemudian diisi oleh Gajah enggon, yang kemudian diganti oleh Gajah Lembana, namun namun patih patih tersebut tidak sekuat patih pendahulunya yaitu Gajah Mada (Muljana, 1983:223).

Setelah keruntuhan Kerajaan Majapahit meninggalkan prasasti, candi, kitab dan lain-lainnya yang menceritakan tentang kehidupan Kerajaan Majapahit. Salah satu peninggalan yang masih terkenal adalah Kitab Nagarakertagama karangan Mpu Prapanca menceritakan sebuah perjalanan hidup dari Maha Raja Hayam Wuruk.

Candi yang di bangun oleh para pendahulunya Maha Raja Hayam Wuruk adalah candi Brajrajinaparamita yang kemudian disebut sebagai Candi Jabung oleh masyarakat setempat. Lokasi candi berada di Dusun Candi, Desa Jabung, Kecamatan Paiton Kabupaten Probolinggo. Candi berbahan bata, berlatar belakang agama Buddha, berasal dari abad XIV Masehi atau 1276 Saka/1354 Masehi, berdasarkan angka tahun yang dipahatkan pada ambang pintu masuk.

Sebagai salah satu tempat sejarah di Kabupaten Probolinggo Candi Jabung sangat dijadikan sebagai objek pariwisata sejarah. Akan tetapi penggunaan Candi Jabung masih minim digunakan dalam pembelajaran sejarah di masyarakat karena keadaan dilapang parawisatawan hanya datang untuk berpariwisata tanpa melihat adanya potensi yang dimiliki oleh Candi Jabung dalam dunia pendidikan, pada 
HISTORIA: Jurnal Program Studi Pendidikan Sejarah Volume 7 (2) 2019

ISSN 2337-4713 (E-ISSN 2442-8728)

penelitian ini akan meneliti kajian tentang nilai nilai yang ada pada candi jabung yang dapat bermanfaat dalam bidang pendidikan dimata pelajaran sejarah.

\section{METODE}

Penelitian ini termasuk dalam penelitaian deskriptif kualitatif karena hasilnya berupa kalimat kalimat yang didapat dari sebuah teori yang dikembangkan untuk menunjukan suatu fakta yang pada akhirnya akan ditarik sebuah kesimpulan berasal dari kalimat kalimat dan fakta yang diperoleh oleh peneliti, Bertujuan mencapai sasaran, penelitian yang berjudul "Nilai Nilai Edukasi Candi Jabung Kabupaten Probolinggo Terhadap Pelajaran Sejarah"

Pada penelitian ini menggunakan pendekatan kualitatif, sedangkan dalam lokasi penelitian ini berada pada Desa Jabung Candi, Paiton, Probolinggo, JATIM. Penelitian ini menggunakan peralatan beruap, rekorder, kamera dan lembar hasil data yang akan didapat.

Pada metode pengumpulan data yang akan diambil peneliti memutuskan menggunakan beberapa cara yakni : Teknik penentuan informan, dalam penelitian ini peneliti menggunakan snow ball sampling yaitu dengan mencari satu responden yang mengetahui sedikit banyak tentang objek yang akan diteliti yaitu candi jabung yang nantinya setelah selesai peneliti akan bertanya tentang orang lain yang responden itu mengerti tentang objek yang kan di teliti ( melompat seperti bola sesuai anjuran responden pertama dan setetusnya) peneliti akan menghentikan pertanyaan kepada respondejika dirasa data yang diperoleh sudah cukup. Pada penelitian ini peneliti juga menggunakan pendekatan purposive sampling yaitu menentukan responden kunci yang dikira mengetahui apa yang sedang diteliti oleh peneliti. Sehingga peneliti memutuskan untuk responden pertama peneiti memilih penjaga candi jabung sebagai awal langkah untuk mencaris sumber, peneliti memilih penjaga candi karena penjaga candi setiap hari berinteraksi dengan candi dan masyarakat sekitar objek yang akan diteliti.

Teknik pengumpulan data pada teknik inilah data data akan dikumpulkan yang nantinya akan digunakan dalam mencari titik terang dari pertanyaan yang telah ada dan dijabarkan kemudian disimpulkan. Peneliti memilih untuk pengumpulan data menggunakan teknik observasi, teknik wawancara, teknik studi dokumen/pustaka.

Teknik wawancara, menurut Nasution, teknik wawancara atau interview merupakan suatu bentuk komunikasi verbal atau semacam 
percakapan untuk memperoleh informasi. Tujuan dari teknik ini adalah untuk mengetahui apa yang terkandung dalam pikiran dan hati orang lain. Nantinya setelah dilakukan pencarian data yang dilakukan dengan wawancara ini akan dilakukan observasi secara langsung pada objek oleh peneliti dengan melihat kenyataan kenyataan yang ada pada objek menyesuaikan apa yang dikatakan responden.

Pada pencarian data yang terakhir adalah dengan studi dokumen, setelah data wawancara dan data observasi didapatkan maka studi dokumen dilakukan oleh peneliti dalam mencari kebenaran data yang ada dilapangan dengan mencari dokumen dokumen yang mendukung dengan hasil dari data wawancara dan data observasi.

Teknik pengolahan data/ anlisis data pada penelitian ini nantinya akan dijelakan dalam bentuk kalimat karena penelitian diskriptif kualitatif yang menekankan pada data yang valid dan bukan dalam bentuk pengukuran namun menggunakan deskripsi.

Pengumpulan data yang telah dilakukan antinyakan akan disusun dan dikembangkan dengan jelas dengan menggunakan pemikiran yang logis untuk mencari fakta fakta yang akan ditemukan dalam menjawab pertanyaan yang telah ditentukan sebelumnya oleh peneliti kemudian peneliti akan menarik kesimpulan jawaban yang telah didapat pada pertanyaan yang sebelumnya.

\section{HASIL DAN PEMBAHASAN}

Nilai agama, candi jabung ini adalah sebuah candi yang berfungsi sebagai sebuah makam, makam yang diaksud adalah makam dari sanak famili dari keluarga maha raja hayam wuruk yang disebut dengan bhre gundal saudara dari nenek raja hayam wuruk. Pemujaan dilakukan di candi tersebut pada saat kedatangan raja hayam wuruk di Kalayu tersebut. Jika dilihat candi merupakan bangunan suci yang digunakan sebagai tempat pemujaan, makan rakyat setempat beranggapan bahwa orang yang dikubur dalam candi tersebut suci. Maka semua sanak famili raja dianggap sebagai perwakilan dewa yang patut disembah atau dipuja.

Pintu candi berada bagian atas candi yakni dibagian atap candi yang mendakan sebuah perjalanan menuju tepat yang paling suci menuju moksha, perjalanan yang dilakukan oleh keluarga raja hayam wuruk sudah berada pada tahapan yang terakhir yakni kesucian.

Nilai kreatif, candi jabung pada masih terdapat nilai nilai seni yang masih dapat dilihat hingga sekarang candi jabung memiliki ukiran ukiran yang sangat cantik pada bagian bagian yang berada pada kaki, tubuh, dan kepala candi dengan ukuran sulur sulur dan daun daun, namun ukuran tersebut 
HISTORIA: Jurnal Program Studi Pendidikan Sejarah Volume 7 (2) 2019

ISSN 2337-4713 (E-ISSN 2442-8728)

pada saat observasi ukurannya mulai terkikis dan tidak tampak lagi namun masih ada relief yang masih tampak.

Ukiran-ukiran yang ada pada candi jabung seperti ukiran naga, ukiran seorang dewi menaiki ikan, seorang pertapa bersorban putih dan anak didiknya, dua ekor singa saling berhadapan. Ukiran yang terbuat tersebut menganduk makna yang dalam pada kehidupan. Ukiran tersebut diukir dipermukaan batu bata yang kuat. Jika dilihat dari umur candi yang sudah tua namun ukiran ukiran yang detai dan melambangkan suatu makna masih dapat dilihat hingga sekarang.

Nilai ingin tahu, candi jabung dapat dimanfaatkan dalam pembelajaran disekolah dengan keberadaanya dimasa kini yang sangat misterius sehingga dapat dijadikan sebagai bahan ajar dari sejarah peninggalan peninggalan yang dilakukan oleh leluhur bangsa indonesia.

Candi Jabung juga memiliki nilai kehidupan yang didapat dari leluhur bangsa indonesia terutama dari kerajaan Majapahit yang beragama buddha. Candi Jabung memiliki makna yang mendalam dalam kehidupan misalnya candi jabung memiliki tiga bagan tubuh yakni atap candi, tubuh candi, dan kaki candi, masing masing gaian tubuh candi tersebut memiliki arti yang baik dalam kehidupan manusia. Pada bagian candi paling bawah adalah kaki candi yang melambangkan sebuah kehidupan dunia yang masih melekat dengan apa yang disebut dengan nafsu duniawi. Tubuh candi berada antara atap candi dan kaki candi bagian candi ini melambangkan kesucian pada mahluk hidup namun masih memiliki sifat keduniawian. Atap candi merupakan bagian yang paling tinggi yang melambangkan kesucian atau mahluk suci (dewa) dari bagian candi tersebut dapat dilihat yetang tingkatan kehidupan yang ada pada kehidupan di dunia.

Nilai rasa cinta tanah air, pada unsur ini candi jabung memiliki rasa cinta pada tanah air yang dapat di tanamkan pada anak didik untuk mengagumi seluruh peniggalan kerajaan kerajaan pada masa lampau sehingga akan menimbulkan rasa cinta pada tahan NKRI, rasa cinta tanah air akn berkembang jika kesenangan akan benda purbakala ada. kesenangan yang dimaksd adalah rasa cinta akan peninggalan lelulurnya yaang begitu megah dan indah.

Kesenangan yang didapat siswa juga berpengaruh pada pembelajaran sejarah dikelas, pembelajaran sejarah dianggap sebagai pembelajaran yang kurang menyenangkan yang hanya membahas tentang masa lampau, maka dengan adanya rekreasi/kunjungan dengan pembelajaran berbasis outdoor lerning ini akan memberikan dampak kepada peserta didik dalam kelas bahwa 
tidak selamanya pembelajaran sejarah membosankan. Selain dapat menjadi tempat hiburan peserta didik juga akan mendapat pengetahuan baru dengan lingkungan penelitian sejarah.

Nilai pelindung lingkungan, pada unsur ini candi jabung ini juga memiliki unsur yang dapat dimanfaatkan dari rasa cinta tanah air sebelumnya, karena kekaguman yang didapat dari rasa cinta tanah air tersebut otomatis peserta didik akan menjaga dan melerstarikan lingkungan termasuk pada unsur unsur peninggalan sejarah dengan didukung oleh rasa senang yang dimaksudkan tadi pada nilai cinta tanah air.

\section{PENUTUP}

\section{Simpulan}

Pembahasan yang telah dilakukan diatas dapat memberikan kontribusi dalam pembelajaran sejarah untuk peserta didik dalam kelas dengan pengetian dan nilai nilai yang terkandung dalam candi jabung, kandungan yang terdapat pada candi antara lain nilai agama, nilai kreatif, nilai ingin tahu, nilai cinta tanah air dan nilai perlindung lingkungan yang dapat ditumbuhkan dari peserta didik saat kunjungan.

Bagian bagian candi memiliki nilai nilai yang dapat di jadikan seuah pembelajaran dalam sejarah menunjang materi dan nilai kehidupan pengetahuan yang didapat lebih banyak dalam bidang kehidupan ya1ng dapat juga diaplikasikan ke pendidikan agar peserta didik dapat mengetahui arti kehidupan sesungguhny dengan melihat peninggalan sejarah nenek moyangnya dimasa lalu dengan cara observasi langsung.

\section{Saran}

Berdasarkan hasil bahasan yang dilakukan, Candi Jabung dapat digunakan sebagai pembantu dalam pembelajaran sejarah disekolah karena memiliki nilai-nilai dalam edukasi dan sebaiknya guru di sekolah memberikan contoh nyata yang berada di lingkungan sekitar tempat tinggal peserta didik.

\section{DAFTAR PUSTAKA}

Suhardana, KM. (2008). Nagarakertagama \& pararaton: sejarah pembanganunan majapahit. Surabaya: paramita.

Muljana, slamet. (1983). Pemugaran persada sejarah leluhur majapahit. Jakarta:inti idayu press.

Saktianti, damaika dkk. (2015). Kakawinan nagarakertagama. yogyakarta: Narasi.

Istari, T.M rita. (2015). Ragam hias candi candi dijawa motif dan maknanya. Yogyakarta: kepel press.

Awang, Imanuel sairo. (2017). Strategipembelajaran: tinjauan umum bagi pendidik. sintang: STKIP persada khatulistiwa. 